Original Research Paper

\title{
Indonesia Network Infrastructures and Workforce Adequacy to Implement Machine Learning For Large-Scale Manufacturing
}

\author{
Steven Anderson ${ }^{1}$, Ansarullah Lawi ${ }^{2}$ \\ ${ }^{1}$ PT. Riau Andalan Pulp \& Paper. Indonesia. \\ ${ }^{2}$ Faculty of Engineering, Universal University. Indonesia.
}

Article History

Received:

19.12.2020

Revised:

27.02.2021

Accepted:

12.06.2021

*Corresponding Author:

Steven Anderson

Email:

stevenandersonlim@gmail.com

This is an open access article, licensed under: $\mathrm{CC}-\mathrm{BY}-\mathrm{SA}$

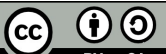

Abstract: Technological development prior to industrial revolution 4.0 incentivized manufacturing industries to invest into digital industry with the aim of increasing the capability and efficiency in manufacturing activity. Major manufacturing industry has begun implementing cyber-physical system in industrial monitoring and control. The system itself will generate large volumes of data. The ability to process those big data requires algorithm called machine learning because of its ability to read patterns of big data for producing useful information. This study conducted on premises of Indonesia's current network infrastructure and workforce capability on supporting the implementation of machine learning especially in large-scale manufacture. That will be compared with countries that have a positive stance in implementing machine learning in manufacturing. The conclusions that can be drawn from this research are Indonesia current infrastructure and workforce is still unable to fully support the implementation of machine learning technology in manufacturing industry and improvements are needed.

Keywords: Digitalization, Machine Learning, Manufacturing, Network Infrastructure. 


\section{Introduction}

Various manufacture industries are making the transition to digitalization following the concept of Industrial Revolution 4.0. The concept of Industry 4.0 gives incentive for industries to digitalize, especially during this modern economy for two reasons. The first reason is the rapid rate of progress in the field of innovation which can open up a new market for innovative technology. Then the second reason is the high effectiveness rate which is expected to solve global industrial problems in the modern era [1]. In order to meet economic demands and compete in global competition, all countries are urged to take steps to make a transition, including Indonesia. The 4.0 industrial revolution aims to create a manufacturing factory that involves artificial intelligence through cloud computing, internet of things and cyber physical systems. The collaborative design will lead to developments in monitoring and decision-making systems. One of the main keys to the application of artificial intelligence technology is decision making according to the rules, premises and objectives that have been described. The accuracy rate will be increase by processing past historical data and updated new data [2]. The basis of ability in decision making by artificial intelligence is due to several functions contained in it. The first step, learning process is to study patterns from data, this function can run with or without human supervision. The second step, reasoning process is to process the data into information through various methods and so on. This ability imitates human rational thinking. This helps artificial intelligence study patterns to be generated into information. Then the third step, interacting process, the interaction function covers human's instruction to machines. These interactions create collaboration in carrying out tasks within the industry environment. As in the case being studied in a research, artificial intelligence in a hazard warning system where there is an interaction of an intelligence system that has learned abnormal patterns in the system and gives warnings to machines that are the source of problems or person in charge [3]. Quick and precise decisions are needed in an industrial situation that has problems and dynamic changes due to the flexible demands in the manufacturing industry in variety or quantity.

Machine learning is one of the fast growing branches of computer science. Machine learning, as the name implies, is a technology that gives computers the ability to learn without having to be completely programmed like conventional algorithm. Machine learning is only programmed to fulfill an objective or several and accept input. Thus machine learning will generate its own logic by learning pattern in data. With automated learning capabilities, machine learning can act, develop, and process data into information with the input that has been given to meet the goals that have been programmed. There are two reasons why we use machine learning instead of direct or conventional programming. First, because some jobs are too complex to be programmed, such as jobs that require detailed analysis of large and complex amounts of data for example astronomical weather data. Conventional programming will take a lot of times and potentially miss out several key programs needed to process data. Second is the adaptability of machine learning, the limitation of conventional programming is its rigidity, once the program has been created, it cannot change drastically. On the other hand, machine learning adapts and changes according to its input. These two aspects are the reasons for the creation of machine learning in hope that the program can learn patterns and keep itself updated according to the data that has been input in the database [4].

\section{Background}

According to the World Economic Forum's annual report in 2019, Indonesia's competitive level fell five ranks from 2018 to rank 50 out of 141 countries. From the scope of South East Asia, Indonesia is ranked 4th after Singapore, Malaysia and Thailand. One of the measurement rubrics is the adoption of information and communication technology (ICT). In terms of ICT adoption, Indonesia is ranked 72nd out of 141 countries [5]. According to the Indonesian Ministry of Communication and Information, the quality of education in the ICT sector is still ranked 8th in South East Asia [6]. This has resulted in a shortage of human resources who are proficient in the field of ICT which will result in Indonesia having difficulties in undertaking digitization steps. The limited number of human resources in programming or coding expertise is one of the challenges in digitizing progress for industry in Indonesia. The unmet demand for workforce in information technology with industry becomes one of the major factors that holding the progress. This condition in line with report from the national occupation map in the field of information and communication technology (ICT) produced by the Indonesian Ministry of Communication and Informatics [6]. One example is the technology company Karya Anak Bangsa LLC mobile application called Gojek, which is the Indonesia version of 
Uber. It is one of the biggest decacorn startup in Indonesia and the increasing popularity and number of app downloads is encouraging companies to increase the number of programmers in order to strengthen their applications. Lack of local human resources that meet the job requirement in Indonesia forcing Gojek to outsources programming services to India. Gojek currently opens a recruiting center in Bangalore, India to recruit programmers in India for Gojek [7]. This was a huge lost in opportunity to utilize local workforce. On one side it gave glimpse that ICT education in Indonesia unable to fully support digital company.

In line the government's move for the Golden Indonesia program in 2045, namely 100 years of Indonesian independence. Where in 2045 Indonesia is projected to get a demographic bonus. It's give projection of the productive population reaching $70 \%$ of the total population and the dependency ratio rate decreasing to $50 \%$. So Indonesia is capable to reach the top 5 economic rankings by 2045 . In order to achieve this target requires economic growth of $5.1 \%$ per year at the very least [8]. Network infrastructure development and increasing workforce capabilities are included in the government's programs [9]. In improving the domestic economy, Indonesian industry must be able to follow and adapt to the dynamics of technological development. The time gap between 2020 and 2045 must become the timeline to improve the infrastructure and human resources capability in order to prepare the generation that will take part as workforce in the year of 2045. Aside from the preparing the work force, infrastructure development must build or improve in order to give large-scale manufacture chance to transit becoming digital industry before 2045 target. The current global trend give the glimpse that the creative and digital industry will become the future of the global economy. In an effort to adapt the global economy, it is necessary to implement updated technologies and skills that require increasing industrial competitiveness in Indonesia [10].

Based on the problems that has been stated, this paper provides studies of Indonesia current infrastructure and workforce in realizing the development of the domestic digital industry in achieving the 2045 Indonesia target. Where Indonesia large-scale manufacture has implemented digital industry in order to increase competitiveness. The application of machine learning in the industry is one of the supporting factors in the digitalization step to increase the capability of the domestic industry in terms of production till producing a quality product. The implementation of machine learning in the largescale manufacture heavily takes account on the adequacy of the network infrastructure and the workforce in Indonesia. So this research examines on industry, infrastructure and human resources adequacy in Indonesia in order to give report regarding whether machine learning can be implemented or not. A side form studying the current condition of the workforce and infrastructure.

This study will also dwell on the current regulation and infrastructure program on whether government program are in right course in realizing domestic digital industry. Which raise the following questions:

1. Does Indonesia currently have adequate infrastructure in the implementation of machine learning Technology for the Indonesian industry?

2. Does Indonesia currently have adequate skilled workforce that supports the implementation of Indonesian industrial machine learning technology?

Research objectives from analysis in this paper are to provide an overview of whether machine learning technology that can be implemented in large scale manufacture and to find out the needs in efforts to implement machine learning technology in the industry. This later can be linked to find out whether machine learning technology can be implemented in Indonesia considering Indonesia's current conditions in terms of infrastructure and human resources.

\section{Method of Research}

This section describes how research is conduct and method on collecting data for research. First, the mechanism on how to collect data and source of the data used in the research and method of collecting the data. Second, on method and technique for analyze data that been collected.

\subsection{Data Source and Method of Collecting Data}

The data collection method will be carried out by the literature study method where the way to collect data is by reviewing books, literature, notes and reports that have a relationship with a careful object [11]. In this study the data are in the form of things related to machine learning which are relevant to the problem formulation of the research. 
To ensure the validity of the data, researchers pay attention to the characteristics of good secondary data, namely [12]:

1. Data reliability: Reliability can be tested by finding out things like about the data:

a) Who collects data?

b) Where are the data sources from?

c) Were they collected using the proper methods?

d) In what period was the data collected?

2. Data match: Data that matches one question may not always be found to be suitable for another. Therefore, if the available data did not match, it was not used by the researcher. The suitability is measured the topics discussed by the research data which provide information about the research variables. The researcher must carefully examine the definitions of the various terms and collection units used when collecting data from the original primary source. Likewise, the object, scope and nature of the original investigation must also be studied. If the researcher finds a difference in this, the data are not suitable for the study and should not be used.

3. Data sufficiency: If the level of accuracy achieved in the data is found to be inadequate for the purpose of this investigation, they will be deemed inadequate and should not be used by the researcher. Data will also be considered inadequate, if it relates to an area that may be narrower or wider than the area under study. Where the scope of the data used in the study is proportional to the scope under study. For example, the readiness of human resources in implementation on a national scale using the number of workers on a national scale instead of a regional scale. The data used is proportional to the scope under study.

In research the data used will be selected through data reliability criteria to ensure the quality of the data sources that will be used, such as those published in certain journals that have a certain index. Then from the research results, it can be traced whether the data has relevance to the object being discussed such as whether the industry in research is an industry that is the scope of research. The final step of data research must have a high degree of accuracy with a sufficient number of samples in the research that is the source of the data. This can be measured through the index of the journals that published the research.

To ensure that the research uses relevant data, it is necessary to check the validity of the research data by means of the triangulation method, which is one of the credibility testing methods which can be interpreted as checking data from at least three sources to ascertain whether other studies also produce the same arguments or whether the research findings. Can be replicated. So thus obtained triangulation of sources, data collection techniques, and data collection time. Research data from sources such as journals, articles, documents, statistics, etc. will be cross-checked with other data sources to confirm the validity of the data that has been obtained, such as ensuring the validity of news articles from media $\mathrm{X}$ being examined by other media, namely media $\mathrm{Y}$ and $\mathrm{Z}$ which also report same news also [13].

After data triangulation, the second method is to make continuous observations on the object under study. This step is carried out by making continuous observations of the subject under study, in order to understand the symptoms more deeply, they can find out important aspects according to the focus of the study [14].

\subsection{Data Analysis Methods and Techniques}

This study uses the first method, namely descriptive analysis of primary data, with this method the research can describe the data used in the study. There are three steps in the data analysis process, namely [15]:

1. Prepare the data to be analyzed.

2. Analyze the data that has been collected.

3. Interpret the analyzed data such as reviewing the discussion and conclusions of the study.

The second method of this research is the comparative method on secondary data, with this method research can compare two or more types of similar data in order to make comparisons [13]. Comparisons are made with the following mechanisms:

1. Data that have similar conditions / research objects, such as two or more studies discussing 
the curriculum of several countries in ICT education.

2. The data have similar research objectives, such as the example of two or more studies having the aim of implementing machine learning.

3. The data is carried out in a similar scope, such as an example of two or more research on the use of machine learning conducted in the same industrial sector

The data give various results on similar research but in different conditions, it may produce different or the same output, such as comparisons of educational curricula between countries in building human resources. These comparisons serve as benchmarks, with comparative data providing descriptions of different conditions across studies. For example, with the $\mathrm{X}$ factor in two studies, the results of the two studies achieved the same thing, it was proven that factor $\mathrm{X}$ influenced the phenomenon. In another case, with the presence of the $\mathrm{Y}$ factor in one study and the absence of the $\mathrm{Y}$ factor in another study, the results of the two studies still achieve the same thing, it is proven that the $\mathrm{Y}$ factor does not affect a phenomenon. From this comparison, it can be seen that the factors that influence or do not affect a phenomenon. The purpose of the comparison is to ensure that these factors are the factors that influence the successful implementation of machine learning in the industry.

In analyzing the data, there are three flows of activities, namely data reduction, presentation of funds and drawing conclusions from research data [16].

1. Data reduction is the process of selecting, focusing on simplifying, abstracting, and transforming the raw data that emerge from the study. Reduction is carried out since data collection, starting with making a summary, exploring themes, etc., with the intention of setting aside irrelevant data or information, and then the data is verified.

2. Presentation of data is the process of describing a set of information that can provide the possibility to draw conclusions. The presentation of qualitative data is arranged in the form of narrative text, with the aim of being designed to combine various information in a coherent and easy to understand form.

3. Drawing conclusions is the final activity of qualitative research. Researchers come to conclusions and must verify, both in terms of meaning or validity of conclusions from the research carried out. The conclusion from the data is obtained through a review of the research results and research conclusions. The research that becomes the data will be checked again for the consistency of the research between the formulation of the problem, the research objectives and the research results. The meaning formulated by the researcher from the data must be tested for truth and conformity

\section{Finding}

This section describes the finding of the research regarding the capability of Indonesia current infrastructure and human resources for implementing machine learning in large-scale industry compound, which first describes the urgency of industry to implement machine learning, followed by case being studied in Indonesia infrastructure condition and lastly the human resources capability

\subsection{The Urgency of the Digital Industry for Large-Scale Industries in Indonesia}

In various studies suggests that a decision-making algorithm is needed in an industry where the tool will be assigned to manage the data collected by detection tools such as sensors and so on. The size of the industrial scale has an impact on increasing the amount of data that needs to be inputted. Due to the large amount of data it takes artificial intelligence, namely machine learning, in processing data into useful information. Studies concluded that without added value, industry decision maker will not make the transition to updated digital technology. To make digital technology useful, Artificial intelligence algorithm are needed to manage data that has been collected from devices that collect data resulting in added value to an industry.

The importance of the transition to the digital industry in Indonesia is due to the fact that Indonesia's manufacturing production capacity is still not optimal, which is the result of the Bloomberg Purchasing Managers Index (PMI) Report. It shows that for 1.5 years the Indonesian manufacturing index has been stagnating and has begun to deteriorate since the pandemic [17]. This index shows the domestic manufacturing capability requires various changes in order to increase the domestic industry in motive to get out of the stagnation zone.

Even though countries such as China and South Korea have both experienced stagnation and decline. This does not have a negative impact on the country's manufacturing industry because in terms of their 
contribution to manufacturing output is very high. The amount of output is included in the top ten, with China alone accounting for $28.4 \%$ of global manufacturing in term of value added [18]. Indonesia still contributed less than $1 \%$ in the same year, this proves that Indonesia's manufacturing potential has not been fully utilized. In fact, in terms of natural resources and population, Indonesia has a step ahead of other countries. The seven countries on the list have very limited resources and are below Indonesia in term on population but can make it into the top ten in the ranking of contributors in manufacturing.

Apart from the value of Indonesia's output which is still below 1\%, production growth is also an indicator of manufacturing conditions in Indonesia. China's annual industrial production growth tends to be more stable, compared to Indonesia's which is more volatile [19]. It is very difficult to improve the ranking and contribution of Indonesian manufacturing at the global level at a time when growth is difficult to control.

In general, most manufacturing industry in Indonesia still uses a conventional coordination system which still uses a written medium in coordination between humans and the use of machines. This makes it difficult to monitor and control the production process and the flow of information is not integrated. This proves making it difficult to create any useful data from production. It requires to design and implement a digital system in order to generate real-time reports and information on the conditions of the manufacturing line [20].

So companies are encouraged to digitize the industry by starting to implement the digital industry system to facilitate remote monitoring and control. In establishing the digital industry system, the system itself is inseparable from data processing and data analysis as the core of the use and function that needed in digital technology to digitalizing industrial process. The system cannot run without a process of managing and analyzing data which can result in investment in digital hardware such as sensors and other automation tools will not generate any added value to process, thereby reducing the motivation and urge of industry stakeholder to digitalize [21].

Running the system properly will depend on artificial intelligence to be able to manage complex data and become a lot of information and reports that can be used by industry decision maker to make decisions and supervision [22]. Machine learning technology will be one of the proponents of the successful digitization of the industry. Machine learning capabilities are needed to be able to speed up decision making to avoid time waste that occurs in the decision making process for industry decision maker and to be able to make decisions by itself with the requirements that have been programmed from the machine learning.

Machine learning needed in manufacturing that requires a lot of resources and materials. In order to get the profit, the manufacture must operate efficiently, delays will hamper production and cause waste in terms of time and cost. Machine learning technology is needed in the production process, machine learning can be applied as a detection of delays that occur in industry to a complex level as a decision-making tool [23]. This application will help the company to run well from an operational perspective.

The urgency for Indonesia to start digitizing the industry is very concrete in the steps to improve Indonesia's manufacturing capabilities. Digitalization can increase the manufacturing competitiveness of a country. Competitiveness is measured by the industry's ability to meet the needs of a dynamic and volatile market. Processing data on market needs and manufacturing plants that can properly accept and adapt to these large changes is an indication of the success of the improvement. Increasing the competitive level can be an opportunity for the Indonesian industry to be in the spotlight and can increase the capabilities and output of the industry [2].

To support industrial digitization, the application of machine learning is needed. For industry decision maker, without data processing tools, investment in automation tools will be unproductive. The presence of machine learning technology will encourage industry decision maker to invest in automation tools to do the transition to industrial digitalization in Indonesia will be successful. The inhibition of industrial digitization has made domestic manufacturers not fulfill their potential well. This is evident from the fact that Indonesia's manufacturing value is still below $1 \%$. To improve manufacturing capabilities, it is very important to take industrial digitization steps to be competitive and flexible in meeting market needs. This can be successful with the existence of machine learning as a supporting instrument for industrial digitization.

The application of machine learning technology is very minimal in Indonesia considering its huge potential in helping industrial operations run. For example Gojek products with a large coverage covering South East Asia countries have not been able to implement machine learning based on the statement of the founder and CEO of Gojek Nadiem Makarem in the Gojek Podcast titled "GOFIGURE PODCAST" [24].

Without a data processing tool that can work well with large quantities of data sourced from digital 
technology, there is very little consideration for transitioning to digital technology in manufacturing for industry decision maker because it does not generate added value. With successful digitization supported by machine learning, it can improve manufacturing capabilities. Well-known startup companies like Gojek are still unable to use the machine learning system in their company. Indonesia's PMI has stagnated during 2019 and Indonesia's output production capacity is still below the top 10, where countries with large populations and resources such as China, India and the United States can be ranked 10th in the total output of the manufacturing industry. Indonesia as a country with a large number of human and natural resources has not yet optimized the resources available in Indonesia. The industrial digitization step is an effort to increase the competitiveness of countries globally. The implementation of machine learning is one of the factors supporting the digitalization steps of the domestic industry. On the other hand, machine learning is the first step in implementing artificial intelligence, where developed countries like the United States have started the transition from machine learning to Deep Learning to Quantum Deep Learning. So it is very important to take the first steps as early as possible to increase industry capability by adopting renewable technology.

\subsection{Indonesian Network Infrastructure Conditions for Machine Learning}

To function well in industry, the machine learning system in industry implementation consists of data collection, learning process and implementation process. The data collection and implementation process uses technologies outside of machine learning program itself. The system will need data collected by other device as input and other device to execute the decision [25]. To be able to implement the system successfully, infrastructure is needed to support all of the three processes. The data collection process may depends on the type of data needed which means the data will be diverse and require a lot of various external device to collect useful data. Lack or wrong type of data will generate big margin of error thus the system will produce wrong information. Aside from data collecting to implement decision or coordinate with other device as well to provide report to user properly is the objectives of the system in the project or task. According to various research concluded that there is the same technology in the machine learning training process that is network infrastructure to coordinate input, process and output of the system with other device as an integrated system in industry.

Network infrastructure is very important to support the implementation of machine learning systems integrated to industrial system. Based on the Global Connectivity Index report, Indonesia still ranks 64th out of 79 countries in terms of connectivity. It is still not optimal compared to Singapore, which ranks 2 and Malaysia 32. In the report by Huawei, Indonesia places Indonesia in the third category, namely beginners in terms of network technology development. There are still 2 categories above, namely the two categories of adopters and the top position of the leader [26].

The technology that supports the digital industry has not yet reached the world average index and even compared to South East Asia countries, Singapore and Malaysia in terms of Broadband and Cloud availability. Significant improvements in development indicators are needed. Where development and development are still only focus on $4 \mathrm{G}$ coverage which shows an increase. Mobile broadband subscription rates and smartphone penetration peaked last year. $4 \mathrm{G}$ coverage in Indonesia continues to increase, as is the total number of Internet users. But broadband infrastructure still at slow pace and small subscription base. Slow development of fixed networks is holding back the country from trying to grow a digital industry using ICT equipment [26].

It is still necessary to develop infrastructure that supports connectivity and technology. Where the level of investment on infrastructures is still at an average level to below average, except for investment in $4 \mathrm{G}$ technology. State connectivity is still not optimal form in supporting the industry compared to other South East Asia countries such as Malaysia and Singapore which have the level of development and investment higher than Indonesia current level. The current infrastructure conditions support the application of machine learning technology is still not optimal as investment are not in the highest compare to other South East Asia countries and don't get the primary focus as the attention still on mobile connectivity [26].

One area that can be improves in term connectivity for business and manufacturing is by providing high quality broadband access throughout Indonesia. By creating better communication access to telecommunications and information for manufacturing companies. From the report of the World Economic Forum Competitiveness Index in 2019, in terms of infrastructure development, Indonesia still ranks 72 out of 141 countries. Where broadband access is still ranked 97 out of 141 countries [5]. Data from the Internet Service Providers Association shows in 2016 that the population with internet access is still $38 \%$ of the total population. Of that $38 \%$ that have access, only 30 percent use broadband while $70 \%$ come from smart phones [27]. Where according to a report from the World Economic Forum in 2019 the access rate is still 
$39.8 \%$ of the adult population [5].

Aside from incomplete coverage, there is a problem regarding the speed of broadband itself, where Indonesia is still around 20.1 MBPS on national average according to the Hootsuite report in January 2020. Where is still below the world average of 73.6 MPBS [28]. Speed is very influential on the performance of the data input process for machine learning. This condition is caused by geographical factors from Indonesia, so there are difficulties in the process of increasing speed and equal access. Until 2019 there were still 24,000 villages without internet access [29]. Only 9 provinces out of 34 provinces have a communication and information technology development index above the national average. Based on Indonesia Agency on Statistics data report for 2018 [30]. Those nine provinces has common similarity, those region are mostly urban area. Thus the current development are still focus on urban region rather than the potential resources that can be utilize from the region.

This hampers the industrial digital transition because the places that support this transition are still centered on large cities which mean the possibility of interrupting communications from upstream to downstream industries is very likely. And in other hand industry will find difficulty in building plant with low network coverage in most case they drop to build plants there. In the digitalization project, connectivity must be comprehensive in all regions there's must be integration from upstream to downstream to facilitate the production process from raw to finish product. The successful implementation of machine learning is also very dependent on connectivity because flow of input and output to be process by machine learning require network that can deliver those data and information for the system to work properly. Any disruption or disconnection of access hampers the performance of the technology as whole. For machine learning technology to work effectively, steps are needed that can accelerate the development of physical infrastructure or the implementation of technology that can help build connectivity in all areas from remote places, rural region to metropolitan cities. To achieve the industrial digitization require government focus on development of communication and information infrastructure that support network connectivity.

\subsection{Conditions of Workforce for Machine Learning in Indonesia}

Competent workforces are one of the main factors for success in industrial digitization. According to research it was stated that education about digital knowledge is very important prior to digital revolution [4]. It is encouraged that every country is able to create a workforce that can adapt to dynamic technological developments. With workforces that has good digital knowledge will support the development and economic growth of a country. Seeing industry trends for the transition to digitization, it is very important for prospective workers able to adapt and support digitalization [31].

Various sources consistently state that human resources for the field of information and communication technology (ICT) in Indonesia are still far from optimal. According to data by Ministry of National Development Planning of Indonesia, shows that Indonesia's population is 271 million people and is predicted to reach 300 million in 2035. An increasing population will have an impact on domestic business growth. As the population grows, the number of companies and businesses will increase as workforces are increasing. Human resources are needed to be fully prepared in order to mobilize and support domestic business development [32].

According to the statement of the Minister of Industry, by 2030 Indonesia needs 17 million people who will work in the information and communication technology sector, where around 680 thousand or $4 \%$ of the total workforce needed will be allocated in the manufacturing sector [33]. According to a study conducted by AT Kearney. Indonesian education can still only produce 278 ICT workers for every 1 million population. With this current pace the demand on 2030 won't be fulfill. This figure is also still small compared to other Asian countries such as Malaysia which can produce 1,834 ICT workers for every 1 million population and India can produce 1,159 ICT workers for every 1 million of their population [32]. The shortage of workers is an obstacle to the digitalization transition step. The absence of competent human resources will hinder the growth and development of the manufacturing sector going forward. This will lead to stagnation or competitive decline of domestic manufacturers because the transition step is threatened with being delayed due to a lack of human resources to support it.

The competitiveness of Indonesian workers is still not optimal where in 2018 it was still ranked 47th globally, far below Malaysia which was ranked 28th and Singapore was ranked $13^{\text {th }}$ [34]. Based on Indonesia Central Agency on Statistics data on labor absorption in February 2019, the educational background of Indonesian workers is still dominated by elementary school graduates as much as $40.51 \%$ of the total workforce in 2019 and university graduates make up only $10 \%$ of the total [35]. For graduates from the university alone, only $14 \%$ of the total numbers of students have engineering backgrounds. Of these 
$14 \%$ only half graduate taking ICT related degree [36]. Indonesia currently lacks of graduates with the skills needed to support the digitalization transition of various sectors.

The National Labor Force Survey in 2015 showed that in general $60.52 \%$ of respondents stated that there was a mismatch of job qualifications with educational background [34]. These data show that although graduates come from ICT engineering, not all of them are absorbed in the sector of the appropriate field of their competence. This is in line with the statement of the Minister of National Development Planning that out of around 100,000 engineering graduates only about 5,000 work in fields according to their profession [37].

This resulted the growth of the manufacturing sector to be hampered due to the lack of resources suitable for the required profession. For machine learning itself, there are still very limited resources that can operate it, access to machine learning in Indonesia is still initiated by an international company, namely Google, but this education is still focus on training rather than a full pledge course in university and has not significantly increased workforce capable of using machine learning [38]. The machine learning is not use optimal in industry because human resources are still limited and human resources are not allocated to the appropriate professions to design and implement the machine learning technology.

Barriers also arise for university graduates, where graduates are faced with industries that have different demands from what their studied at university. This is not exclusive to Indonesia because this phenomenon occurs globally, various countries are encouraged to update the education curriculum to prepare prospective workers with relevant and needed skills after the Industrial Revolution 4.0. [31].

Singapore has an education system that can produce good Science Technology Engineering and Math (STEM) learning. This is reflected in their level of competitiveness, which is ranked 13th globally. The Singapore government designed the education system to be adaptive to current market needs [31]. This is evidenced by the examination made by the OECD research agency, namely the Program for International Student Assessment, or better known as the PISA Test. The test of knowledge and ability is carried out directly on the student as research subject with internationally approved metrics. Singapore is ranked 2nd globally with 2nd in the mathematics category and 2nd in the natural sciences category. Indonesia is still in 6th place from the lowest rank, where from the mathematics category it is 7th from the lowest and 9th from the lowest for the natural science category [39]. Singapore's strategy towards technology development is embedded in one of their strategic programs Build Strong Digital Capabilities. One of the universities of the Singapore National University of Singapore (NUS) decided that in 2018 to enter a compulsory ability, namely Computational Thinking which consists of statistics and programming lessons for all study programs in the University [31].

This step is also adopted at the elementary school level where elementary school students will receive 10 hours of education in coding and programming subjects in 2020. A subject called Code For Fun is to build basic Computational Thinking skills which they will further learn at the university level. In addition for students to build basic for CT skill, it is also making it easier for students to grasp Computational Thinking logic from an early age, this step will also ensure that all prospective workers have the ability to code regardless of the concentration they will choose in the future [40].

The Indonesian education system also applies Computational Thinking skills but is still too exclusive to certain majors or concentrations. From the 2013 curriculum as the current standard for the national education curriculum, only vocational school majors with computer concentrations such as software engineering get computational thinking education. At the university level only undergraduate computer majors such as Informatics Engineering get advanced learning for computational thinking education. There are non-formal educational institutions that provide software programming courses. However, the participants from vocational school, undergraduate computer major and training courses are very limited. For example the ratio of high school and vocational school in 2016 where high school take $67 \%$ and vocational school take $33 \%$ of the total student attend in high school and vocational school. Even these schools are at the same educational level in Indonesia only one of them gets access on computational thinking education and vocational school itself is still divided into various departments which mean that $33 \%$ of those students, only small percentage getting the computational thinking education [41].

Meanwhile the syllabus studied by students at the high school level according to the Regulation of the Minister of Education and Culture (Permendikbud) of the Republic of Indonesia define Information and Communication Technology as one of thirteen subjects of choice for students, where students choose only 2 of the 13 subjects to choose from. 
According to Permendikbud number 36 year 2018 which clearly stated as below.

"Informatics is one of the disciplines that functions to give human thinking ability in overcoming increasingly complex problems in order to compete in the 21st century. Information and Communication Technology as a part of Informatics is a basic need of students in order to develop their abilities in the digital era. Informatics Subjects are selective subjects that are organized based on the availability of teachers according to academic qualifications and competencies, as well as infrastructure in educational units. Time allocation for Informatics Subject in Class X is 3 hours of lessons; Class XI and XII each with 4 hours of lessons"

Source: (Permendikbud number 36 year 2018) [42]

This step to put Information and Communication Technology as selective not compulsory subject is highly not recommended considering various incidents up to the obstacles that could potentially occur during the prospective employee's education period. Prospective workers are not ready to face the latest and latest technological advances in the future.

Various studies state that there are obstacles for Indonesia students to make career decisions. Students' careers in Indonesia tend to be chosen by other parties. The autonomy component in career selection is quite low among students. This does not indicate that students cannot choose their career but most of them do not or lack courage in career choice [43]. The condition faced by Indonesian adolescents where Eastern Culture, namely the involvement of parents in decision making in adolescent life, is still very large. This will have a bad impact if parents as decision voters do not receive updated information regarding the latest developments, which decisions are only based on the most recent information they have. There is an effect of family social support on student stability in career choices, namely as much as $30.8 \%$. There is a relevance where the higher the family support, the increased the students' stability with their career choices and vice versa where the lower the support the more doubtful students are about their career choices [44].

In addition to the involvement of parents, there is still a lack of career guidance services from the school where three factors are still a concern for schools in Indonesia, namely information quality which are insufficient amount of information and inconsistency in information regarding careers [43]. According to a survey conducted, it shows the students lack of ability to explore career choices as result. Lack of career guidance services makes students unable to determine their own career direction. So the result is that $77 \%$ of the sample cannot make career decisions by themselves. Where $70 \%$ of the sample still depends on other parties, namely parents in career choices [45]. The step of change is not appropriate to make ICT subjects an option where the decision for selecting subjects will be adhered to by other parties and lack of update on current information regarding career.

Whereas technological developments nowadays urge all individuals to have ICT capabilities. On the other hand, if these subjects are also based on availability and are not required, so even though the subjects are selected, they still face obstacles to access due to the understaff of capable teacher. Moreover, various studies show that ICT education in Indonesia is still uneven. Apart from the lack of teaching staff, infrastructure development to support ICT education is still not develop and lack of socialization to the public regarding the importance of ICT. The area will experience stagnation and even worse under develop regarding the development of knowledge and utilization of ICT [46].

As a whole in Indonesia, the absent of ICT education will worsen students' knowledge of technological developments and the abilities needed to utilize technology in solving problems of everyday life. If the high school student chooses a major related to information and communication technology in university, the student is not prepared with the skills needed to carry out his studies properly. Where there are two alternatives, namely students leaving the study program or university forcibly having to allocate credits to teach these students so students can catch up with the subject or graduate with abilities that are still less than those required for the profession.

In the current curriculum, ICT lessons at the elementary and junior high school levels are also removed from the syllabus and integrated into other subjects as stated in Permendikbud number 36 year 2018.

"That in order to meet the basic needs of students in developing their abilities in the digital era, it is necessary to add and integrate informatics content on basic competencies in the basic framework and structure of the 2013 curriculum at the primary and secondary education levels"

Source: (Permendikbud No 36 of 2018) [42] 
However, it doesn't mean that elementary and junior high school students will get better education related to information and communication technology. Mostly the practice result only student getting ability to only use it not able to necessary design or understand the logic of the technology. This further result in problem as there are no clear definition of the law related what is consider as digital technology. As in research conducted on ICT implementation in language subjects where the user is only limited to using technology tools and facilities such as the example of using LCD TV to provide a visual image in effort for students can compose stories from image displayed on the LCD. Thus it doesn't reflect the current technology that should have been informed to the student. The studies of technology in current curriculum doesn't obligate educators to explain aspects related to technology because based on the concepts of the current syllabus, ICT is only a learning media tool not a learning object [47]. In fact, students' perceptions show that students feel that ICT knowledge must have its own separate and compulsory subjects [48].

The government must overcome the problem of not fully prepared student with ability to use computer programs in solving problems. These problems arise because of the lack of access and opportunities to get programming education. Although the chosen career does not require specific ICT knowledge, technological developments and digitalization urge all workforce to be able to start adopting the use of technology to facilitate their work. According to research by the World Economic Forum, the Future of Job Survey, considering the condition of the ratio of male and female workers which is still consistent throughout 2020, predicts that for every STEM job that appears 4 jobs are lost for men and 20 for women [31]. It is important for the education system to ensure that all prospective workers are educated about ICT knowledge to face technological developments. Where Singapore has started implementing coding education for students as a step to deal with technological changes after the industrial revolution 4.0. the current condition of education of Indonesia will only produces limited workers who undergo ICT education to be able to optimally utilize technology. Where the current condition is still limited to $7 \%$ of the total graduates who work and are only able to produce 278 per 1 million populations [32]. If all workers receive an average ICT education regardless of majors or concentrations like Singapore, they can individually use technology to help complete their work. It avoids limited resources capable of supporting the transition to digitalization of industries or other sectors.

An effective industry is where all the components in the industry can work in synergy and move as a unit for it to run well. For example, the flow of information from the marketing department to the production department is very important for the production department can produce according to the order quantity. Likewise, the ability of using digital technology is not exclusive to IT engineers. Considering the big impact in industry and all sectors in the industry, all professions can use digital technology as tool. Where machine learning field can be an interdisciplinary study between various concentrations [4].

This step can be started from all engineering study programs throughout Indonesia to be able to study and use machine learning technology in resolving problems or examples of cases in the industry. Both electrical engineering engineers to industrial engineering must have access to programming education to implement machine learning technology in their respective professional fields where at this time not all engineering study programs include courses related to programming, especially machine learning program. Graduates only get abilities relevant to the profession but are not prepared for the development and utilization of digital technology.

To be able to directly learn machine learning technology directly at the university level, the foundation of ICT education, including coding, must be entered early as in Singapore at the elementary level. At the university level students no longer need to allocate time to learn the basics of coding at the university level or incur financial costs to take programming courses. In particular, the programming language used by the both machine learning frameworks PyTorch [49] and TensorFlow [50] which are using programming language like Python, C +, CUDA. Python, C +, CUDA. Coding knowledge and skills are needed from an early age to support the implementation of machine learning in professions in the industry. In particular, the Python language is often used in machine learning design with two dominating frameworks, namely Tensorflow and PyTorch.

ICT lessons are must be a compulsory subject for students from elementary to high school levels, and it is recommended that the program language be a special subject such as language subjects. A survey conducted by Oraco Technology in the UK shows that the Python language program is much more popular to learn than French at the elementary level [51]. There is an attempt to classify the program language as a language. Where technically it can be classified as constructed language and not natural language. Where it fulfills the function of language, namely communicating between entities, in this case humans and computers [52]. 
For machine learning itself, there is very limited access to be able to learn machine learning system design specifically only done by Google in its machine learning Crash Course (MLCC) program in Indonesian. So it is necessary to increase access to training where it is recommended to enter the formal education curriculum in Indonesian universities as a practicum for language education programs and work aids in accordance with the prospects of each department [38]. Formal education can include all learners rather than through training and courses. The number of prospective workers who can use program language increases and is able to design machine learning systems as practicum. Apart from language skills, statistical skills and probability programs are also needed in making and reading the results of machine learning output. Thus mathematics lessons, especially statistics and probability, are prioritized for prospective workers to be applied to machine learning technology [53]. It takes steps to improve mathematical skills for prospective workers in Indonesia as a foundation for technology to run and its good use in Indonesia and to increase the PISA Test score in the mathematics category.

\section{Conclusions}

In accordance with the results of research that has been done, several conclusions can be drawn, which can be elaborated as follows:

1) The implementation of Machine Learning increases the efficiency and productivity of manufacturing where it shows that its use can increase efficiency, productivity and quality consistency so as to increase industrial capability. The competitive level of the domestic industry increases this can result in increased production levels. Increasing the number of products with good quality can improve the country's economy. The implementation of Machine Learning can increase the number of quality output contributions globally.

2) The current level of infrastructure in Indonesia is still unable to support the successful implementation of machine learning in the industry. Where there is still room for improvement in terms of broadband availability. The main problem is the lack of equal coverage of digital infrastructure in various regions. Most development is heavily focus on urban area, meanwhile the most industry will build its plant closer to the resources which mean low network coverage in this case. Thus having focus on urban area doesn't fully give support the development of the digital industry using machine learning especially those that are based in rural. Development must base on equity that put priority on development in all regions so it can connect upstream to downstream industries in the flow of information. Also it will reduce industry cost in logistic as they are closer to the resources, utilize region resources and bring economic development to those region as well. It is hoped that these improvements can support accelerating the implementation process so as to increase the capability of Indonesia's domestic industry. Within the scope of South East Asia countries, Indonesia still does not have a level of investment and development equal to other South East Asia countries such as Singapore and Malaysia in order to increase connectivity infrastructure for companies. The development of digital supporting infrastructure can be the main program in increasing the success of the digital transition for the domestic industry.

3) The current condition of human resources in Indonesia is still unable to support the successful implementation of machine learning in the industry. There is a shortage of workforce in supporting industrial digitization using machine learning, where graduates from universities in Indonesia only produce $14 \%$ of students with technical backgrounds. Of these $14 \%$ only half or $50 \%$ of thoses possess ICT skill. Indonesian education can still only produce 278 workers in the ICT sector for every 1 million population, this figure is still far from a country like Malaysia, which is 1,834 ICT workers for every 1 million population, so it is necessary to increase the number of Indonesian workers who are competent in the ICT field. Necessary ICT education is given to all concentrations of fields of study, not only exclusive to students of vocational with computer major or university students of ICT Department. To increase the number significantly, the application of ICT learning must covers all majors or concentrations in Indonesia. All departments can use technology to solve problems in their respective fields of concentration without having to focus on ICT majors. There is also a problem for the workforce, namely the mismatch of job qualifications so it is very important to have relevant technology education in the digital era to provide knowledge to prospective workers about the development and utilization of technology. Prospective workers are prepared in a dynamic 
technology development. A program is needed that can create a creative workforce that can take advantage of technology.

The research conducted has found several problems that still need to be resolved, so there are several suggestions for parties who have an interest in the steps to implement Machine Leaning in the Indonesian manufacturing industry. The following suggestions can be given to interested parties in the implementation of machine learning:

1) Formal and non-formal educational institutions must be able to make technology education easily accessible for all levels of society and various regions have the opportunity to learn and apply technology in everyday life. All prospective workers are able to support industrial digitization steps without having to heavily relying only on Computer Engineering graduates. As well as prospective workers can get access to technology education regardless their future preferred majors or concentration.

2) Research is still limited to case studies in order to illustrate the implementation of machine learning in Indonesia. It is necessary to conduct further studies on quantitative aspects such as calculating the investment costs of machine learning system technology at the time of implementation in manufacturing companies in Indonesia to complete the study. The implementation of machine learning in the Indonesian industry has a more concrete analysis. And it is necessary to research on implement the continuation of machine learning technology such as Deep Learning to Quantum Deep Learning technology.

\section{Acknowledgments}

The authors greatly appreciate to Research and Community Services, Universal University, Indonesia, for supporting in technical assistances.

\section{References}

[1] E. G. Popkava, J. V. Ragulina, and A. V. Bogoviz, "Industry 4.0: Industrial Revolution of the 21st Century," Switzerland: Springer International Publishing, vol. 169, 2019.

[2] K. Kaushik, Z. Divya, and D. J. Paulo, Industry 4.0 Developments towards the Fourth Industrial Revolution. Singapore: Springer Singapore, 2019.

[3] C. Jordi and H. Franz, the Future of Management in an AI World: Redefining Purpose and Strategy in the Fourth Industrial Revolution. London: Palgrave Macmillan, 2020.

[4] S. S. Shai and B. D. Shai, Understanding Machine Learning: From Theory to Algorithms. New York: Cambridge University Press, 2014.

[5] S. Klaus, The Global Competitiveness Report 2019. Geneva: World Economic Forum, 2019.

[6] A. Bintoro, Indonesia Darurat Tenaga Programmer. CNN Indonesia, 2017. [Online]. Available: https://www. cnnindonesia.com/teknologi/20170728094848-185-230919/indonesiadarurat-tenaga-programmer. [Accessed: September 2020].

[7] P. Aditya, Banyak Dipesan, Gojek Rekrut Programmer India. CNN Indonesia, 2015. [Online]. Available: https://www.cnnindonesia.com/teknologi/20151022143648-185-86640/banyak-dipe san-gojek-rekrut-programmer-india. [Accessed: September 2020].

[8] S. Deandra, Jadi Negara Maju pada 2045, Ekonomi Indonesia Akan Bergantung pada Startup. Bisnis.com, 2019. [Online]. Available: https://teknologi.bisnis.com/read/20190724/266/112815 0/jadi-negara-maju-pada-2045-ekonomi-indonesia-akan-bergantung-pada-startup. [Accessed: September 2020].

[9] D. R. Kartika and H. Sari, Jokowi Sebut Cita-cita Indonesia di Tahun 2045. Kompas, 2019. [Online]. Available: https://www.kompas.com/tren/read/2019/10/20/190800865/jokowi-sebutcita-cita-indonesia-di-tahun-2045-apa-saja-?page=all. [Accessed: September 2020].

[10] R. H. Kusumo and S. Mulyani, Ungkap Syarat RI Jadi Negara Maju pada 2045. CNBC Indonesia, 2020. [Online]. Available: https://www.cnbcindonesia.com/news/202001131224194-129544/sri-mulyani-ungkap-syarat-ri-jadi-negara-maju-pada-2045. [Accessed: September 2020].

[11] N. Moh, Metode Penelitian. Bogor: Ghalia Indonesia, 2014. 
[12] C. R. Kothari, Research Methodology: Methods and Techniques. 2nd. New Dehli: New Age International Publishers, 2009.

[13] Sugiyono, Metode Penelitian Kuantitatif, Kualitatif dan R\&D. Bandung: Alfabeta, 2018.

[14] J. M. Lexy, Metode Penelitian Kualitatif. Bandung: PT Remaja Rosdakarya, 2017.

[15] M. Geoffrey, D. David, and F. David, Essentials of Research Design and Methodology. New Jersey: John Wiley \& Sons, Inc, 2005.

[16] H. Usman and A. P. Setiady, Metodologi Penelitian Sosial. Jakarta: Bumu Aksara, 2006.

[17] Bloomberg, How the World's Purchasing Managers See Current Business Conditions, 2020. [Online]. Available: https://www.bloomberg.com/graphics/global-pmi-tracker/?srnd=economic s-vp. [Accessed: September 2020].

[18] R. Felix, These Are the Top 10 Manufacturing Countries in the World. World Economic Forum, 2020. [Online]. Available: https://www.weforum.org/agenda/2020/02/countries-manufacturingtrade-exports-economics/. [Accessed: September 2020].

[19] Trading Economics, Indonesia - Pertumbuhan Produksi Industri (y-on-y). New York: Trading Economics, 2020.

[20] M. Pane, R. Hartono, Y. Yuwana, and S. Raharno, "Implementation Concept of Industry 4.0 to Manufacturing Industry in Indonesia in Order to Optimize Supply Chain Management," Advances in Intelligent Systems Research, vol. 171, pp. 155-160, 2019. [Online]. Available: https://doi.org/10.2991/icoemis-19.2019.22. [Accessed: September 2020].

[21] H. Max, Smart Agents for the Industry 4.0: Enabling Machine Learning in Industrial Production. Wiesbaden: Springer Vieweg, 2019.

[22] Suharman and H. W. Murti, "Kajian Industri 4.0 Untuk Penerapannya Di Indonesia," Jurnal Manajemen Industri dan Logistik, 2019. [Online]. Available: https://doi.org/10.30988/jmil.v3i1. 59. [Accessed: September 2020].

[23] L. Pedro, Industrial Application of Machine Learning. London: CRC Press, 2018.

[24] Go Figure Podcast, Realistic Approaches to Machine Learning At Gojek. Go Figure Podcast (Episode 4), 2019. [Online]. Available: https:/gofigure.gojek.com/transcript/episode-4-realis tic-approaches-to-machine-learning. [Accessed: September 2020].

[25] C. Josh, the Surprising Truth about What it takes to build a Machine Learning Product. Medium, 2019. [Online]. Available: https://medium.com/thelaunchpad/the-ml-surprisef54706361a6c. [Accessed: September 2020].

[26] Huawei, Powering Intelligent Connectivity with Global Collaboration. Shenzhen: Huawei, 2019.

[27] P. Y. Manggala, Jumlah Pengguna Internet Terus Meningkat. Republika, 2016. [Online]. Available: https://www.republika.co.id/berita/nasional/daerah/16/06/21/o94r87284-jumlah-peng guna-internet-terus-meningkat. [Accessed: September 2020].

[28] R. F. Christy and W. A. Yakti, Kecepatan Internet RI Nyaris Terendah, Menkominfo Sebut 6 Sebab. Tempo, 2020. [Online]. Available: https://bisnis.tempo.co/read/1338150/kecepataninternet-ri-nyaris-terendah-menkominfo-sebut-6-sebab/full\&view=ok. [Accessed: September 2020].

[29] S. Eva, Kominfo: 24.000 Desa Belum Tersentuh Layanan Internet. Detik Inet, 2019. [Online]. Available: https://inet.detik.com/telecommunication/d-4505284/kominfo-24000-desa-belum-ter sentuh-layanan-internet. [Accessed: September 2020].

[30] Tim Peneliti Puslitbang SDPPI, Studi Percepatan Penetrasi Akses Fixed Broadband. Jakarta: Kementerian Komunikasi dan Informatika, 2018.

[31] N. W. Gleason, Higher Education in the Era of the Fourth Industrial Revolution. Singapore: Palgrave Macmillan, 2018.

[32] S. Eko and P. W. Destiana, Jumlah Insinyur IT Indonesia tak Sesuai Kebutuhan Perusahaan. Republika, 2018. [Online]. Available: https://republika.co.id/berita/nasional/umum/18/03/01/ p4wuzu359-jumlah-insinyur-it-indonesia-tak-sesuai-kebutuhan-perusahaan.

[Accessed: September 2020].

[33] S. Sidik, Siapa Minat, RI Butuh 17 Juta Tenaga Kerja IT. CNBC Indonesia, 2019. [Online]. Available: https:// www.cnbcindonesia.com/tech/20190312195140-37-60263/siapa-minat-ributuh-17-juta-tenaga-kerja-it. [Accessed: September 2020]. 
[34] Kata Data, Daya Saing Tenaga Kerja Indonesia Masih Tertinggal, 2019. [Online]. Available: https://katadata.co.id/infografik/2019/05/16/daya-saing-tenaga-kerja-indonesia-masihtertinggal. [Accessed: September 2020].

[35] Kata Data, Lulusan SD Masih Mendominasi Angkatan Kerja di Indonesia, 2019. [Online]. Available: https:// databoks.katadata.co.id/datapublish/2019/05/22/lulusan-sd-masih-mendomi nasi-angkatan-kerja-di-indonesia. [Accessed: September 2020].

[36] Lavinda and Antara, Indonesia Disebut Kekurangan Pasokan Insinyur Hingga 280 Ribu. CNN Indonesia, 2018. [Online]. Available: https://www.cnnindonesia.com/ekonomi/2018050922 1524-92-297076/indonesia-disebut-kekurangan-pasokan-insinyur-hingga-280-ribu. [Accessed: September 2020].

[37] A. Damianus, Kepala Bappenas Keluhkan Jumlah Insinyur di Indonesia Masih Minim. Tirto, 2018. [Online]. Available: https://tirto.id/kepala-bappenas-keluhkan-jumlah-insinyur-diindonesia-masih-minim-damE. [Accessed: September 2020].

[38] A. M. Khory and P. Erwin, Google Luncurkan Kursus Machine Learning Berbahasa Indonesia. Tempo, 2018. [Online]. Available: https://tekno.tempo.co/read/1154236/google-luncurkankursus-machine-learning-berbahasa-indonesia/full\&view=ok. [Accessed: September 2020].

[39] S. Andreas, PISA 2018. Paris: OECD, 2019.

[40] B. Hariz, Enrichment classes on coding for all upper primary pupils next year. Straits Times, 2019. [Online]. Available: https://www.straitstimes.com/tech/coding-to-be-made-compulsoryfor-all-upper-primary-pupils-next-year. [Accessed: September 2020].

[41] Indriani and R. T. Tri, Kemdikbud tingkatkan persentase jumlah SMK Negeri. Antara News, 2016. [Online]. Available: https://www.antaranews.com/berita/569509/kemdikbud-tingkatkanpersentase-jumlah-smk-negeri. [Accessed: September 2020].

[42] Datadikdasmen, Permendikbud No. 36 Tahun 2018 Tentang Kurikulum K13, 2018. [Online]. Available: $\quad$ http://www.datadikdasmen.com/2019/01/unduh-pdf-permendikbud-nomor-36tahun.html. [Accessed: September 2020].

[43] H. C. Mamahit, "Hubungan Antara Determinasi Diri dan Kemampuan Pengambilan Keputusan Karir Siswa SMA,” Psiko-Edukasi, 2014. http://ojs.atmajaya.ac.id/index.php/fkip/article/view/ 297. [Accessed: September 2020].

[44] R. J. Widyastuti and T. I. Pratiwi, "Pengaruh Self Efficacy Dan Dukungan Sosial Keluarga Terhadap Kemantapan Pengambilan Keputusan Karir Siswa," BK UNESA, 2013. [Online]. Available: https://jurnalmahasiswa.unesa.ac.id/index.php/jurnal-bk-unesa/article/view/3369. [Accessed: September 2020].

[45] H. Pramudi, Kemampuan Pengambilan Keputusan Karir Siswa Kelas XI Di SMA Negeri 1 Kutasari Purbalingga. Skripsi Universitas Negeri Yogyakarta, 2015.

[46] Y. D. Hadiyat, Kesenjangan Digital di Indonesia (Studi Kasus di Kabupaten Wakatobi). Pekommas, 2014. [Online]. Available: http://dx.doi.org/10.30818/jpkm.2014.1170203. [Accessed: September 2020].

[47] N. Winda, "Implementasi Kurikulum 2013 Dalam Pembelajaran Bahasa Indonesia Berbasis Teknologi Informasi dan Komunikasi," Stilistika: Jurnal Bahasa, Sastra, dan Pengajarannya, 2016. [Online]. Available: https://doi.org/10.33654/sti.vli1.343. [Accessed: September 2020].

[48] N. A. Sasmita, G. S. Santyadiputra, and N. N. Sugihartini, "Persepsi Siswa Terhadap Mata Pelajaran Teknologi Informasi dan Komunikasi (TIK) Antara Sekolah Yang Melaksanakan Kurikulum Tingkat Satuan Pendidikan (KTSP) Dan Sekolah Yang Melaksanakan Kurikulum 2013 Di Kota Kota Singaraja," Kumpulan Artikel Mahasiswa Pendidikan Teknik Informatika, 2016. [Online]. Available: http://dx.doi.org/10.23887/karmapati.v5i3.8760. [Accessed: September 2020].

[49] PyTorch, PyTorch Main Page, 2020. [Online]. Available: https://pytorch.org/. [Accessed: September 2020].

[50] Tensorflow, Tensorflow Main Page, 2020. [Online]. Available: https://www.tensorflow.org/. [Accessed: September 2020].

[51] R. Ben, Python overtakes French as the most popular language taught in primary schools. Information Age, 2015. [Online]. Available: https://www.information-age.com/pythonovertakes-french-most-popular-language-taught-primary-schools-123460073/. [Accessed: September 2020]. 
Steven Anderson, Ansarullah Lawi.

Indonesia Network Infrastructures and Workforce Adequacy to Implement Machine Learning For Large-Scale Manufacturing.

International Journal of Artificial Intelligence, vol. 8, no. 1, pp. 1-16, June 2021. DOI: 10.36079/lamintang.ijai-0801.182

[52] Language Magazine, World Languages vs. Programming Languages, 2015. [Online]. Available: https://www.languagemagazine.com/2015/10/21/world-languages-vs-programminglanguages/. [Accessed: September 2020].

[53] C. Arpan, 5 Skills You Need to Become a Machine Learning Engineer. Udacity, 2016. [Online]. Available: https://blog.udacity.com/2016/04/5-skills-you-need-to-become-a-machine-learningengineer.html. [Accessed: September 2020]. 